九州大学学術情報リポジトリ

Kyushu University Institutional Repository

\title{
New Method For The Determination of Cystine and Cysteine, and Their Application
}

Okuda, Yuzuru

Biochemical Laboratory, Department of Agriculture, Kyushu Imperial University

https://doi.org/10.5109/22327

出版情報：九州大学大学院農学研究院紀要. 1 (4)，pp. 163-196，1925-09. Kyushu Imperial University バージョン：

権利関係 : 
Journal of the Department of Agriculture, Kyushu Imperial University, Vol. I, No. 4 September 1,1925

\section{NEW METHODS FOR THE DETERMINATION OF CYSTINE AND CYSTEINE, AND THEIR APPLICATION}

\section{Yuzuru OKuDA}

Cysteine widespreads in living cells and its oxydation product cystine is found in most of the proteins. Among the amino acids these two occupy an unique place, differing characteristically from the others in the fact that they contain sulphur in their molecules." ${ }^{\text {) }}$ It is a well known fact that amino acids make the peptide and peptine linkages (29) in protein molecules but asicle from these there is the $-S-S-$ linkage in cystine or between two molecules of cysteine. This method of linkacre differentiates cystine from the other amino acids chemically.

The special role of cystine and cysteine in physiology seems to be ascribed to its organic sulphur. DANiELs and RICH (5) have attempted to replace cystine in nutrition with some sulphates but without success The importance of cystine in animal nutrition has been shown by many investigators, as Osborne and Mendel (27), ABderialden (2), and Johns, Jones and Finks (I6). Furthermore the special physiological function of cysteine and cystine in the oxydation and reduction processes in the living cell has been demonstrated lately by Horkins (I 5 ).

These special features of cystine and cysteine aroused the interest of the author and led him to propose new methods for the cletermination of these sulphur-containing amino acids, and to make their determination in proteins and biological solutions.

The present communication consists of the following 6 parts.

1) A new sulphur containing amino acid has been isolated by Mueller (20), but it seems to be uncertain whether it is a primary or secondary product of protein 
Part I. A new method for the determination of cysteine (Bromine-method).

Part II. A new method for the determination of cysteine (Iodine-method).

Part III. A new method for the determination of cystine in proteins (Iodinc-method).

Part IV. The effect of acid lydrolysis upon cystine.

Part V. On the cystine content of proteins.

Part VI. The determination of cystine in urine.

\section{Part I}

\section{A NEW METHOD FOR DETERMINATION OF CYSTEINE}

(THE BROMINE-METHOD)

There are many colorimetric tests for cysteine ; ArNold (3) has compared the quantity of cysteine in animal tissues by means of these colorimetric tests. But it was rather qualitative and not quantitative. As far as I know there is no accurate method for the determination of cystcine.

Friedmann (IO) has found that cystine as well as cysteine are oxidized by bromine and give rise to cysteic acid, but it seems that he did not investigate quantitatively the relation of cystine and cysteine to bromine. Several years ago I (25) studied the quantitative relation between cystine and bromine, and applied this relation to the quantitative determination of the former. In Part $I$ of the present communication a similar investigation about cysteine and a method for the determination of it are to be described.

The principle of the method is to titrate cysteine in an acid solution, in the presence of some bromide, with a standard solution of bromate. This method is very simple, rapid and accurate and requires only a few minutes for a single determination, but can not be used in the presence of some amino acids, such as cystine, tyrosine and tryptophan.

\section{THE RELATION BETWEEN CYSTEINE AND BROMINE}

To know the quantitative relation between cysteine and bromine, the following thrce experiments were performed, which will incicate that one molecule of cysteine is completely oxidized into cysteic acid by mean's of 6 atoms of bromine.

(a). $0.034 \mathrm{~g}$. of cysteine hydrochloride $\left(\mathrm{C}_{3} \mathrm{H}_{7} \mathrm{NSO}_{2} \cdot \mathrm{HCl}\right)$ was mixed with $20 \mathrm{CC}$. of about Io per cent hydrochloric acid and $5 \mathrm{ccc}$. of about 20 per cent sodium bromide, and immediatcly titrated with $M / 20$ potassium bromate solution until a faintly yellow color was obtained. $4.4 \mathrm{c} \mathrm{c}$. of the bromate solution was required.

From this result, calculation was made as follows: The relation between bromate and bromine will be shown by the following reaction, which should take place in the case of the above experiment. 


$$
5 \mathrm{NaBr}+\mathrm{KBrO}_{3}+6 \mathrm{HCl}=5 \mathrm{NaCl}+3 \mathrm{H}_{2} \mathrm{O}+\mathrm{KCl}+6 \mathrm{Br}
$$

From this equation we know that i molecule ( $167.92 \mathrm{~g}$ ) of potassium bromate corresponds to 6 atoms $(479.5 \mathrm{~g}$.) of bromine, or 4.4 c.c. of $\mathrm{M} / 2 \mathrm{O}$ $\mathrm{KBrO}_{3}$ to $0.1053 \mathrm{~g}$. of bromine.

And $0034 \mathrm{~g}$. of cysteine hydrochloride contains $0.026 \mathrm{Ig}$. of cysteine. Consequently one molecule of cysteine ( $12 \mathrm{I} .14 \mathrm{~g}$ ) corresponds to $488.7 \mathrm{~g}$. (about 6 atoms) of bromine.

$$
121.14 \times 0.1053 / 0.026 \mathrm{I}=488.7
$$

(b). $0.034 \mathrm{~g}$. of cysteine hydrochloride was dissolved in 20 c.c. of $\mathrm{Io}$ per cent hydrochloric acid and then titrated with 0.33 per cent bromine water. It required 30.8 c.c. of the solution, which corresponds to 0.1016 g. of bromine.

Therefore the result falls into line with that of experiment (a), namely one molecule of cysteine corresponds to 6 atoms of bromine.

From the results of these two experiments we might assume the following equation to express the relation between cysteine and bromine.

$$
\begin{array}{lc}
\mathrm{CH}_{2}-\mathrm{SH} & \mathrm{CH}_{2}-\mathrm{SO}_{3} \mathrm{H} \\
\mathrm{CH}^{-} \mathrm{NH}_{2}+6 \mathrm{Br}+{ }_{3} \mathrm{H}_{2} \mathrm{O}= & \mathrm{CH}-\mathrm{NH}_{2}+6 \mathrm{HBr} \\
\mathrm{COOH} & \mathrm{COOH}
\end{array}
$$

(c). For the purpose of ascertaining the preceding equation, I made some further investigation.

It is imperative that, if the assumption is correct, the following equation should also hold good.

$$
\begin{array}{ll}
\mathrm{CH}_{2}-\mathrm{SO}_{3} \mathrm{H} & \mathrm{CH}_{2}-\mathrm{SO}_{3} \mathrm{H} \\
\cdot \mathrm{CHNH}_{2}+6 \mathrm{HBr}+7 \mathrm{NaOH}= & \mathrm{CHNH}_{2}+6 \mathrm{NaBr}+7 \mathrm{H}_{2} \mathrm{O} \\
\cdot & \mathrm{COOH} \\
\mathrm{COONa}
\end{array}
$$

Thus one molecule of cysteine must be equivalent to 7 molecules of sodium hydroxide.

To ascertain the relation, two samples of cysteine hydrochloride containing $0.0188 \mathrm{~g}$. each were prepared. The one was directly titrated with $\mathrm{N} / \mathrm{ro} \mathrm{NaOH}$, using azolithmine as inclicator, and the other, after treating with bromine water until a very faintly yellow color was obtained, was also titrated. The results were as follows :

Direct titration... $\quad \ldots \quad \ldots \quad \ldots \quad \ldots \quad \ldots \quad$ I. 3 c.c. $\mathrm{N} / \mathrm{IO} \mathrm{NaOH}$

After treating with the bromine $\ldots 9.8$ c.c. ",

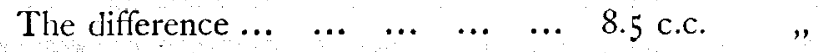


(g). Determination of cystcine from its salts. Cysteine was accurately determined by titration from its hyclrochloride and mercuric chloride double salt.

$\begin{array}{ccc}\text { Sample } & \begin{array}{c}\text { Cystcine } \\ \text { calculated }\end{array} & \begin{array}{c}\text { Cysteine } \\ \text { found }\end{array} \\ 0.14 \mathrm{~g} \text {. of } \mathrm{C}_{6} \mathrm{H}_{14} \mathrm{~N}_{2} \mathrm{SO}_{2} \mathrm{O}_{4} \cdot \mathrm{Hg}_{3} \mathrm{Cl}_{6} & 0.0320 & 0.0323 \\ 0.1278 \mathrm{~g} \text {. of } \mathrm{C}_{3} \mathrm{I}_{7} \mathrm{NSO}_{2} \cdot \mathrm{HCl} & 0.0983 & 0.0960\end{array}$

\section{Part II}

A NEW METHOD FOR THE DETLRMINATION OF CYSTINAE

(THE IODINE-METIIOD)

Although the bromine-method described above is a rapid and accurate method for the determination of cysteine from its solution, the method can not be used if the solution contains some amino acids, such as cystine and tyrosine which also react with bromine.

The iodine-method described here is applicable in the presence of all the cleavage products of the protein. The basis of the method depends upon the fact that among amino acids cysteine alone reacts very actively with iodine, in an acid solution, and at a room temperature. And the principle of the method is to titrate cysteine in hydrochloric acid solution, in the presence of iocline, with a standard iodate solution.

\section{TIIE REACTION OF IODINE CPON AMINO ACIOS}

According to my experiments, cysteine reacts very actively to iodine, but all the other amino acids, known or unknown, which are present in the hydrolysate of casein and gelatine do not react with iodine in hydrochloric acid solution and at room temperature. The results of the following cxperiments will show this fact.

(a). Some cysteine hydrochloride was dissolved in 20 c.c. of two per cent hydrochloric acid solution, and 5 c.c. of 5 per cent iodine solution was added, and then titrated with standard potassium iodate solution until a permanent yellow color of iodine was obtained. The amount of the iodate required was proportional to the quantity of cysteine.

(b). The following amino acids, and the cleavage products of gelatine and casein were subjected to the same treatment as cysteine, but none of them reacted to any iodine, giving a yellow color with a drop of the iodate solution in the presence of iodide and acid. 
Exp. 2. The same experiments were repeated with sulphuric acid with special reference to the time required for titration.

\begin{tabular}{|c|c|c|c|}
\hline $\begin{array}{l}\text { Cysteine } \\
\text { applied }\end{array}$ & $\begin{array}{l}\text { Final Conc. } \\
\text { of } \mathrm{H}_{2} \mathrm{SO}_{4}\end{array}$ & $\mathrm{KBrO}_{3}$ & $\begin{array}{l}\text { Time in } \\
\text { minutes }\end{array}$ \\
\hline c.c. & $\%$ & c.c. & \\
\hline Io & 84 & 2.8 & 2 \\
\hline 10 & $5 \mathrm{I}$ & 2.8 & 2 \\
\hline Io & I. 8 & 2.8 & 6 \\
\hline IO & 0.9 & 2.8 & 20 \\
\hline
\end{tabular}

(c). Concentration of cysteine. The concentration of cysteine in the sample solution has no influence upon the determination.

Exp. I. Io per cent hydrochloric acid solution of cysteine was used.

\begin{tabular}{|c|c|c|c|c|}
\hline $\begin{array}{l}\text { Cysteine } \\
\text { solution }\end{array}$ & $5 \% \mathrm{HCl}$ & $\mathrm{NaBr}$ & $\begin{array}{l}\text { Volume of } \\
\text { solution }\end{array}$ & $\mathrm{KBH}_{3}$ \\
\hline c.c. & $c . c$ & c. c. & $\mathrm{c} \mathbf{c}$ & c.c. \\
\hline 10 & - & 10 & 20 & 245 \\
\hline 10 & 80 & 10 & İo & 245 \\
\hline
\end{tabular}

Exp 2. Sulphuric acid solutions of cystcine in different concentrations were used.

$\begin{array}{ccc}\text { Sample } & \begin{array}{c}\text { Volume of } \\ \text { solution }\end{array} & \mathrm{KBrO}_{3} \\ \text { c c. } & \text { c.c. } & \begin{array}{cc}\mathrm{cc} \\ 10\end{array} \\ 10 & 30 & 2.8 \\ 10 & 60 & 2.8 \\ 10 & 120 & 2.8\end{array}$

(d) The concentration of sodium bromide. No influence was observed as shown in the following experiments.

$\begin{array}{cccc}\text { Sample } & \mathrm{I}_{2} \mathrm{O} & \mathrm{NaBr} & \mathrm{KBrO}_{3} \\ \text { c.c. } & \text { c.c. } & \text { c.c. } & \text { c.c. } \\ 10 & - & 10 & 2.45 \\ 10 & 8 & 2 & 2.45\end{array}$

(e). Temperature. The following solutions in cifferent temperatures were titrated with the same result.

$\begin{array}{cccc}\begin{array}{c}\text { Cystcinc hydro- } \\ \text { chloride applic }\end{array} & \text { Temperature } & \mathrm{KBrO}_{3} & \begin{array}{c}\text { Cysteinc } \\ \text { found }\end{array} \\ \mathrm{g} & \text { (c) } & \text { c.c. } & \mathrm{g} . \\ 0.0235 & 20 & 3 & 0.182 \\ 0.0235 & 33 & 3 & 0.0182 \\ 0.0235 & 52 & 3 & 0.0182\end{array}$

(f). The cleavage products of gelatine which contained minute traces of tyrosine and cystine were alled to cysteine solutions and subjected to the determination.

$\begin{array}{ccc}\begin{array}{c}\text { Cysteine } \\ \text { applied } \\ \mathrm{g}\end{array} & \begin{array}{c}\text { Cleavage } \\ \text { products }\end{array} & \mathrm{KBrO}_{3} \\ \mathbf{0 . 0 1} & \text { not added } & \mathbf{I} .65 \\ 0,0, & \text { added } & \mathbf{I} \cdot 7^{\circ}\end{array}$


$0.0188 \mathrm{~g}$. of cysteine hydrochloride contains $0.01 .45 \mathrm{~g}$. of cysteine. And 8.5 c.c. of $\mathrm{N} / 1 \mathrm{O} \mathrm{NaOH}$ corresponds to $0.034 \mathrm{~g}$. of $\mathrm{NaOH}$. Therefore I molecule of cysteine is equivalent to 7 molecules of sodium hydroxide.

$$
12 \mathrm{I} .14 \times 0.034 / 0.0145=285 \mathrm{~g} . \mathrm{NaOH}
$$

The results of all the experiments mentioned above give rise to the conclusion that one molecule of cysteine corresponds to 6 atoms of bromine, and also to one molecule of potassium bromate. The basis of the brominemethod for the determination of cysteine depends upon this conclusion

\section{THE BROMINE-METHOD}

To 10 c.c. of about 10 per cent hydrochloric (or sulphuric) acid solution of cysteine, add $10 \mathrm{cc}$. of about 20 per cent sodium bromide solution, and then titrate with one twentieth molecular potassium bromate solution, which contains $8.35 \mathrm{~g}$ of $\mathrm{KBrO}_{3}$ in one liter of water, until a light yellow color is produced and remains for 5 minutes. In this case I c.c. of the bromate solution corresponds to $000606 \mathrm{~g}$. of cysteine.

In this determination bromine water can also be used instead of nas. cent bromine, but the latter is more convenient as the bromate solution is stable at least for 6 months, when it is kept in a closed brown glass bottle

\section{TITRATION OF CYSTEINE SOLUTION}

(a). Hydrochloric, and sulphuric acid solutions.

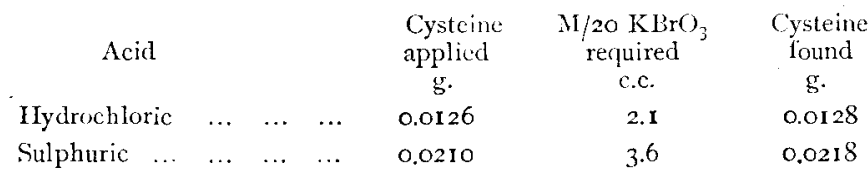

(b). Concentration of acid. The concentration of acid in cysteine solution has no important meaning, but it is convenient to use such an acid colution that the final concentration is about 5 per cent, because in the case of lower acidity, longer time is required to complete the reaction.

Exp. I. Io c.c. of cysteine hydrochloricle solution corresponding to o.or $45 \mathrm{~g}$. of cysteine was treated in different concentrations of hychrochloric acid.

$\begin{array}{ccccccc}\begin{array}{c}\text { Cysteine } \\ \text { applied }\end{array} & \begin{array}{c}20 \% \mathrm{HCl} \\ \text { added }\end{array} & \begin{array}{c}\mathrm{H}_{2} \mathrm{O} \\ \text { added }\end{array} & \begin{array}{c}\mathrm{NaBr} \\ \text { added }\end{array} & \begin{array}{c}\mathrm{Conc} \text { of } \\ \mathrm{HCl}\end{array} & \begin{array}{c}\mathrm{KBrO}_{3} \\ \text { required }\end{array} & \begin{array}{c}\text { Cysteine } \\ \text { found }\end{array} \\ \text { c.c. } & \text { c c. } & \text { c.c. } & \text { c c. } & \% & \text { c.c. } & \text { g. } \\ \text { 10 } & 20 & 0 & \text { 10 } & \text { 10 } & 2.4 & 0.0145 \\ \text { 10 } & 4 & 16 & \text { I0 } & 2 & 2.4 & 00145\end{array}$


(1). Amino acids :-Glycocoll, alanine, valine, leucine, glutamic acid, aspartic acid, proline, tyrosine, phenylalanine, tryptophane, cystine, histidine, arginine andl lysine.

(2). Gelatine cleavage products:- $\mathrm{IO} g$. of gelatine was complctely hydrolysed as usual with hydrochloric acid, evaporated in vacuum into dryness, dissolved in water, decolorized and then made up into Ioo c.c. containing 2 per cent hydrochloric acicl.

(3). Casein clcavage products $:-8 \mathrm{~g}$. of cascin was completely hydrolysed by boilding with baryta, and the baryta was exactly removed by sulphuric acid, and then the solution was made up into 100 c.c. containing 3 per cent of hydrochloric acid.

\section{THE RELATION BETWEEN CISTEINE AND IODINE}

As we now know that cystcine alone reacts to ioline in a certain condition, the next problem was to determine the relation guantitatively. On the first occasion I thought that one of the following reactions would probably take place between cysteine and iodine, namely one molecule of cysteine is oxidized by either one or six atoms of iodine, producing either cystine or cysteic acid respectively.

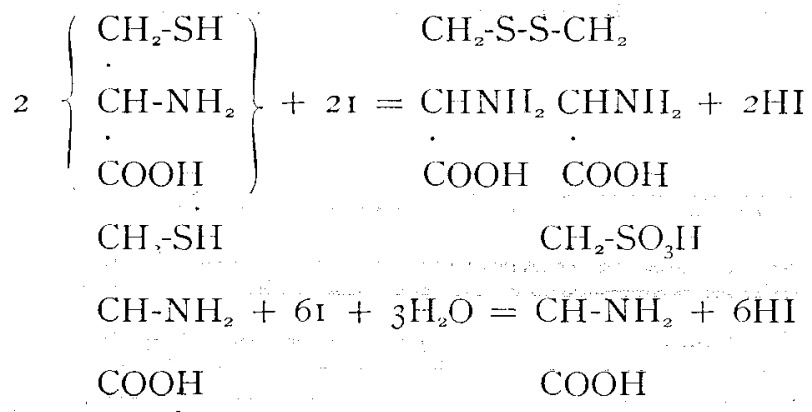

But according to the experimental results shown below, the reaction does not occur in such a simple ratio as shown by the formulae. The ratio varies not only by the concentrations of acid, pottassium iodide, and some other substances in the sample solution, but also by the temperature of the solution.

(a). Concentration of acid. Definite quantities of cysteine and potassium iodide were mixed with hyclrochloric acid solutions of different concentrations, and titrater with a stanklard potassium iodate solution. And the reacting ratio of cysteine and iocine was calculated by means of the equation, $5 \mathrm{KI}+\mathrm{KIO}_{3}+6 \mathrm{HCl}=6 \mathrm{KCl}+6 \mathrm{I}+3 \mathrm{H}_{2} \mathrm{O}$. 


\begin{tabular}{|c|c|c|c|c|c|c|}
\hline \multicolumn{4}{|c|}{ Sample } & \multirow{2}{*}{$\begin{array}{c}\mathrm{M} / \mathrm{IOO} \\
\mathrm{KIO}_{3}\end{array}$} & & Ratio \\
\hline Cysteine & $5 \% \mathrm{kI}$ & $\begin{array}{r}\text { Vol. of } \\
\text { solution }\end{array}$ & $\begin{array}{l}\text { Cone of } \\
\text { IlCl }\end{array}$ & & Time & $\begin{array}{c}\text { Cystein } \\
\text { to }\end{array}$ \\
\hline g. & c.c. & c.c. & $\%$ & c.c. & & Iodine \\
\hline 0.022 & 10 & 130 & 0.33 & 9.6 & $24 \mathrm{hrs}$. & $1 / 33$ \\
\hline 0022 & ro & 90 & 0.47 & 75 & $24 "$ & $1 / 2.5$ \\
\hline 0.022 & 10 & 90 & 1.02 & 60 & $5 \mathrm{mts}$ & $1 / 2.0$ \\
\hline 0022 & 10 & 90 & 3.80 & 4.5 & $2 "$ & $1 / 15$ \\
\hline
\end{tabular}

Similar experiments were also performed with sulphuric acid, and the result obtained in this case was in accord with that made with the hydrochloric acid solution. From these results we see that the higher the concentration of acid, the less iodine is required for a definite quantity of cysteine, and the less time to finish the reaction.

(b). Temperature. 20 c.c. of 2 per cent hydrochloric acid solution containing $0.0 \mathrm{I} \mathrm{g}$. of cysteine was taken in two large test tubes. To each 5 c.c. of 5 per cent potassium iodide and 5 c.c. of 4 per cent hydrochloric acid were adcled, and the tubes were immersed in water of different temperatures, and then titrated with $\mathrm{M} / 300 \mathrm{KIO}_{3}$. As soon as the titration was finished, a thermometer was inserted in the tubes to know the temperature of the liquid. The temperature was $20^{\circ}$ and $25^{\circ}$, and the required volume of the iodate solution was 4.8 and 5.2 c.c. respectively. From these experimental results we see that the ratio of the reacting quantities of iodine and cysteine is influenced by the temperature of the reaction.

(c). Potassium ioclate. As the following experimental results show the concentration of pottasium iodide in the samples has also some influence on the reacting ratio of cysteine and iodine.

\begin{tabular}{|c|c|c|c|c|}
\hline \multicolumn{4}{|c|}{ Samplc } & $\mathrm{KIO}_{3}$ \\
\hline $\begin{array}{l}\text { Cysteine } \\
\text { c.c. }\end{array}$ & $\begin{array}{c}5 \% \mathrm{kI} \\
\mathrm{c} \mathrm{c} .\end{array}$ & $\begin{array}{l}\text { Volume } \\
\text { c c. }\end{array}$ & $\begin{array}{l}\text { Conc. of } \\
\mathrm{HCl}, \%\end{array}$ & c.c. \\
\hline 10 & 5 & 30 & 1.7 & 2.8 \\
\hline 10 & 15 & 30 & I. 7 & 2.5 \\
\hline
\end{tabular}

(d) Chlorides. Sodium chloride has no influence if its concentration in the sample is less than 20 per cent, but higher concentration has some influence.

\begin{tabular}{|c|c|c|c|c|c|}
\hline \multicolumn{5}{|c|}{ Sample } & $\mathrm{K} \mathrm{O}_{3}$ \\
\hline $\begin{array}{c}\text { Cystemo } \\
\text { cc. }\end{array}$ & $\begin{array}{l}\text { KI } \\
\text { c.c. }\end{array}$ & $\begin{array}{l}\text { Volume } \\
\text { cc. }\end{array}$ & $\begin{array}{l}\mathrm{HCl} \\
\%\end{array}$ & $\underset{\%}{\mathrm{NaCl}}$ & \\
\hline 2 & 5 & 30 & 2 & 0 & 9.4 \\
\hline 2 & 5 & 30 & 2 & IO & 9.6 \\
\hline 2 & 5 & 30 & 2 & 15 & 0.5 \\
\hline 2 & 5 & 30 & 2 & 19 & 9.6 \\
\hline 2 & 5 & 30 & 2 & 25 & $7 \cdot 7$ \\
\hline
\end{tabular}


(e). Cysteine. Under the same conditions, the requircment of the iolate solution is proportional to the quantity of cysteine in the samplesolutions.

\begin{tabular}{|c|c|c|c|c|c|c|}
\hline \multicolumn{5}{|c|}{ Sample } & \multirow{2}{*}{\multicolumn{2}{|c|}{$\mathrm{KIO}_{3}$}} \\
\hline Cysteine & Mixture of hydrolysate & K I & Volume & $\mathrm{I}[\mathrm{Cl}$ & & \\
\hline & $\begin{array}{l}\text { of gelatine and casein } \\
\text { c.c. }\end{array}$ & $\mathrm{cc}$. & c c. & $\%$ & c.c. & Ratio \\
\hline I & 10 & 5 & 30 & 2 & 1.15 & IO \\
\hline 5 & 10 & 5 & 30 & 2 & $5 \cdot 70$ & 5.0 \\
\hline 10 & Io & 5 & so & 2 & 10.80 & 95 \\
\hline
\end{tabular}

(f) Amino acids. The hydrolyzed products of casein $(5,5 \% 6)$, and gelatine $(6 \circ \%)$ were separately mixed with cysteine solution and then titrated, at the same temperature in the same volume and in the same concentration of hydrochloric acid and potassium iodide, with a standard i) date solution. As the following results show, the presence of all the cleavage products of casein and gelatine has no influence on the determination of cysteine, if the solution is titrated until the faintly yellow color obtained remains for only one minute, or until "the first yellow." The experimental results are as follows:

\begin{tabular}{|c|c|c|c|c|c|c|c|c|}
\hline \multirow{3}{*}{ No. } & \multicolumn{6}{|c|}{ Sample } & \multicolumn{2}{|c|}{$\mathrm{KIO}_{3}$} \\
\hline & $\begin{array}{l}\text { Cysleine } \\
\text { in } 2 \% \\
\text { IIC } 1\end{array}$ & $\begin{array}{l}\text { Gelatine } \\
\text { hydrolysate } \\
\text { in } 2 \% \text { IHCl }\end{array}$ & $\begin{array}{l}\text { Casein } \\
\text { hyd. in } \\
2 \% \text { IICl }\end{array}$ & $\begin{array}{l}2 \% \\
1 \mathrm{HCl}\end{array}$ & $\begin{array}{l}5 \% \\
\text { Kl }\end{array}$ & $\begin{array}{l}4 \% \\
11 \mathrm{C} 1\end{array}$ & $\begin{array}{c}\text { First } \\
\text { yellow }\end{array}$ & $\begin{array}{c}\text { Last } \\
\text { yellow }\end{array}$ \\
\hline & c.c. & c.c. & c.c. & c c. & c.c. & $\mathrm{cc}$ & c.c. & c.c. \\
\hline 1 & I & - & 一 & 19 & 5 & 5 & 4.75 & 4.75 \\
\hline 2 & I & - & 19 & 一 & 5 & 5 & 4.75 & 500 \\
\hline 3 & $\mathbf{I}$ & 19 & - & - & 5 & 5 & 475 & 4.95 \\
\hline 4 & - & - & 20 & 一 & 5 & 5 & I drop & I drop \\
\hline 5 & - & 20 & - & - & 5 & 5 & I drop & I drop \\
\hline
\end{tabular}

The first yellow color disappeared within a few minutes in samples No. 2 and 3 , and a few drops more iodate solution were required to get the permanent yelluw color or " the last yellow." The phenomenon depends upon the fact that the titration-acidity is equal in all of the samples, but the true acidity of No. 2 and 3 is much lower than that of No. 1 .

From the results of all the experiments mentioned above we came to the conclusion, that the reacting ratio of iodine and cysteine varies uncler different conditions, but other amino acids do not react as cysteine does, consequently under a definite condition, we can determine an unknown quantiiy of cysteine in amino acids mixture, comparing it with a standard solution of cysteine. 


\section{THI: METHOD FOR NES ERMINATION}

For the determination the following solutions are reguired :

( I). About 5 per cent potassium iodide aqueous solution.

(2). Exactly 4 per cent hydrochioric acid.

(3). Exactly 2 per cent hydrochloric acid.

(4). $\mathrm{M} / 300 \mathrm{KIO}_{3}$, which is prepared by dissolving $2.14 \mathrm{~g}$. of pure $\mathrm{KIO}_{3}$ in 3 liters of exactly 2 per cent hydrochloric acid.

This solution should be standardized for the standard cysteine solution, which is prepared by mixing 20 c.c. of exactly 2 per cent hydrochloric acid containing 0.01 g. of pure cysteine ${ }^{2)}$ and 5 c.c. each of solutions ( 1 ) and (2).

For the purpose of the standardization, titrate the cysteine solution with the iodate solution until a yellow color is obtained and then read the temperature of the liquid in a similar manner as described in the preceding part dealing with temperature (Part II, 2, b). The amount of the iodate solution required somewhat differs in different temperatures, for instance $4.65 \mathrm{ccc}$ of the iodate solution corresponds to the standard cysteine solution at $17.5^{\circ} \mathrm{C}$. Consequently it is convenient to make a table or a curve to show the relation between the temperature and the amount of the iodate solution required for the standard cysteine solution, and to use it throughout the experiment. The curve is given in Part III and is therefore omitted here.

Method:-Take $20 \mathrm{c}$ c. of colorless, exactly 2 per cent hydrochloric acid solution containing from 0.005 to $0.05 \mathrm{~g}$. of cysteine, add 5 c.c. each of solutions (1) and (2), and then titrate the mixture with solution (4) until the faintly yellow color obtained remains for one minute, and read the temperature of the liquid. If the temperature is $17.5^{\circ} \mathrm{C}$, the calculation is made as follows :-

$$
\frac{\mathrm{O} . \mathrm{I} \times \mathrm{required} \text { volume of } \mathrm{KIO}_{3}}{4.65}=\text { Cysteine }(\mathrm{g} .) \text { in } 20 \mathrm{c.c} \text {. }
$$

Application of this method. A solution containing o.or $\mathrm{g}$. of cysteine and 2 per cent hyclruchloric acid per c.c. was prepared. And I to 5 c.c. of the solution was made up to 20 c.c. with pure 2 per cent hydrochloric acid (' with 2 per cent hydrochloric acid containing about 5 per cent of amino acids mixture obtained from casein and gelatine. To each of the samples

2) When we have no pure cysteine, the standard cysteine solution can lie readily preparcd from cystine by means of the reduction with zine dust and hydrochloric acid. In this case the purity of the cysteine produced and the concentration of cysteine in the solution can be determined by means of the bromine method described in Part $\mathrm{I}$. 
thus prepared, 5 c.c. each of 5 per cent potassium iodide and 4 per cent hydrochloric acid was added and then titrated with the standard iodate solution, at $17.5^{\circ} \mathrm{C}$

The acidity of all the samples was adjusted so as to be equal, or exactly 2 per cent of hydrochloric acid, using azolithmin as the indicator.

The experimental results follow :

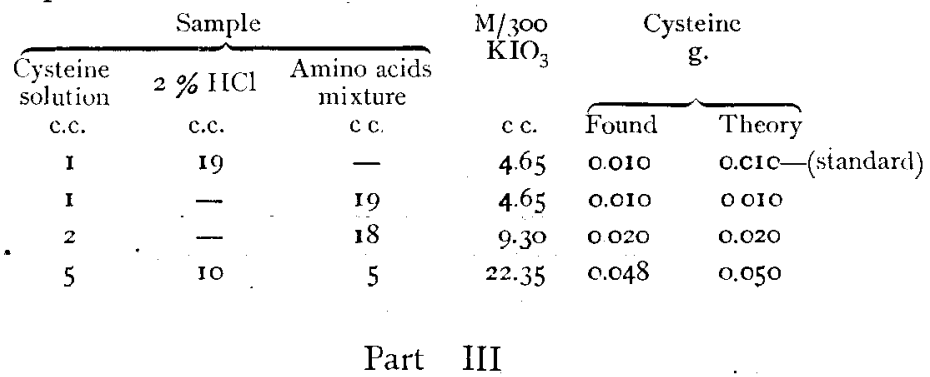

A NEW METHOS FOR THE DETERMINATION OF CISTINE IN PROTINS

(THE IODINE METHODS) ${ }^{3)}$

There are a number of investigations regarding the determination of cystine in proteins; Goldmaxn and Baumann (12), Sutre (32), Schulz (31), Osborne (26), Mörner (19) etc. tried to determine cystine as lead sulphide after heating the protein with caustic alkali. But these methods are not reliable in so far as it is not yet known in what form non-cystine sulphur exists in proteins.

Some authors as Mörner (19), Embden (7), Friedmann (io), Folin (8), and Schmior (30) utilized the fact that the solubility of cystine is comparatively low, and could be easily isolated as a crystal. These methods can be used for the preparation of cystine but not for the determination of it.

Some investigators have obtained not-readily soluble cystine compounds such as phosphotungstate (35), benzoyl derivative (33), mercuric chloride (4), $\beta$ naphthalinsulpho compound (I) and mercuric acetate (22), and tried to make use of them for the determination of cystine But it seems that these compounds can not be utilized for the exact determination, because their precipitation is incomplete, and also some other amino acids make salts as difficult of solution as cystine.

Among the compounds phosphotungstate was used by Plimmer (28) for the isolation of cystine, and by VAN SLYKE (34) for the determination of it. But it was pointed out by Hoffmann and GorTner (I 4 ) that a part of

3) A preliminary paper of this part was already published in the Jounal of Scient. Agr. Soc Japan, $253,7^{84}, 1923$. 
cystine, after boiling with acid, gives rise to an isoner which phosphotungstate is readily soluble. Consequently the phosphotungstate method seems to be insufficient as a method for the determination of cystine.

Lately Folix and Looner (9) devised a colorimetric method, using the uric acid reagent of Folis and Dexis. But some compounds in proteins, other than cystine, give the same color as cystine as will be described in Part V.

Several years ago OKUDA (25) proposed a titration method, which in contrast with the present iodine-method we may name "the bromine method." This method is very accurate and simple, but can not be directly used in the presence of some other amino acids, especially tyrosine.

For the purpose of removing this disadvantage the prcsent investigation was attempted and a new method is described here. This is an application of the iodine-method for the determination of cysteine described in Part II, and based upon the fact that among amino acids cysteine alone reacts very actively to iodine in acid solution and at room temperature. The principle of this method is to reduce cystine into cysteine, and to titrate the cysteine with a standard jodate solution in the presence of iodide and hydrochloric acid.

1. THE RELATION BETWEEN IOMINE AND AMINO ACIOS TREATED WITH NASCENT HYIBROGEN

(a) Cystine :- Some cystine was dissolved in dilute hydrochloric acid and reduced by the addition of some zinc dust. The filtrate was titrated with a standard solution of jodate, in the presence of some iodide, until a yellow color was produced. The amount of the iodate required is proportional to the quantity of cystine, if the titrations are made under comparable conditions.

(b) Other amino acids:-Glycocoll, alanine, valine, leucine, glutamic acid, aspartic acid, proline, tyrosine, phenylalanine, tryptophane, histidine, arginine and lysine were treated in a similar manner as cystine, but their solutions gave a yellow color with only a clrop of iodate solution; that is, after treatment with nascent hydrogen, they do not react to iodine as cystine does.

(c). Mixture of hydrolytic products of protein :-A diluted solution of the hydrolysate of gelatine was treated in a similar manner. It also gave a yellow color with a drop of iodate solution, but a concentrated solution required two or three drops of the iodate solution as the hyclrolysate contains a minute trace of cystine. 
From the experimental results we see that, after treatment with nascent hydrogen, cystine and cysteine alone among amino acids react to iodine under certain conditions, therefore, after reduction, we can easily determine the sum of cystine and cysteine by the iodine method described in Part. II.

\section{REDUCTION OF CYSTINE}

It is a well known fact that cystine is reduced to cysteine by nascent hydrogen, but so far as we know no attempt has been made to show this reaction on a quantitative basis. In order to know the time and concentration of hydrochloric acid necessary for the complete reduction, and also the quantitative relation between cystine and cysteine, the following experiments were performed.

(a). Time:- $-0.282 \mathrm{~g}$. of cystine was mixed with 100 c.c. of 3 per cent hydrochloric acid and a little zinc dust. The mixture was allowed to stand at $20^{\circ}$, being shaken now and then. After an interval of 10 to 240 minutes of reduction, a portion was filtered through with a dry filter paper, and Io c c. each was treated with both the bromine-method (Part I) and the iodine-method (Part II) for cysteine, with the following results.

$\begin{array}{ccc}\text { Time in } & \mathrm{M} / 2) \mathrm{KlirO}_{3} & \mathrm{M} / 3 \mathrm{Co} \mathrm{KIO}_{3} \\ \text { minumes } & \text { c.c. } & \text { c.c. } \\ 10 & 4.65 & \mathbf{1 3 . 5} \\ 40 & 4.65 & - \\ \mathbf{1 2 0} & 465 & - \\ \mathbf{2 4 0} & 4.60 & 13.5\end{array}$

According to the results of the experiments, the reduction was finished within 10 minutes and $0028 \mathrm{I} \mathrm{g}$. (or $4.63 \times 0.0606$ ) of cysteine was produced from $00282 \mathrm{~g}$. Of cystine. It is over $9^{8}$ per cent of the theoretical quantity, as calculated below.

A very small portion of cystine was decomposed during the reduction and evolved as hydrogen sulphide.

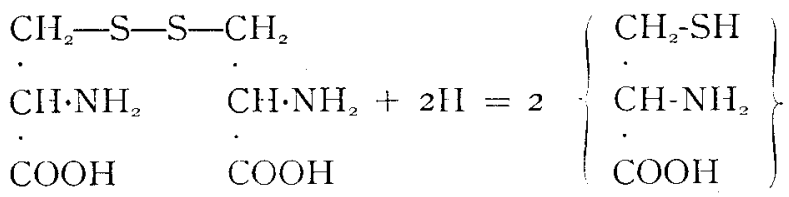

$$
\begin{aligned}
& \frac{0.0282 \times 242.28 \text { (cysteine) }}{240.26 \text { (cystine) }}=0.0284 \ldots \text {...theoretical number } \\
& 0.028 \mathrm{I} \times \mathrm{I00} / 0.0284=98.8 \%
\end{aligned}
$$

(b). Concentration of acid:-In each of 4 test tubes $2 \mathrm{cc}$. of a solution containing $0.0572 \mathrm{~g}$. of cystine was measured, and made up to 
IO c.c. with hydrochloric acid solutions in different concentrations varing from I to I 5 per cent. Some excess of zinc dust was added to each test tube and reduced at $22^{\circ}$ for 30 minutes. They were then filtered separately with dry filter papers, and 5 c.c. each of the filtrates was subjected to the bromine method for the determination of cysteine with the following results.

$\begin{array}{cc}\text { Concentration of } & \mathrm{M} / 20 \mathrm{KBrO}_{3} \\ \mathrm{IICl} & \cdot \\ \mathrm{I} \% & 4.7 \mathrm{c.c} . \\ 3 & 4.65 \\ 5 & 4.7 \\ \mathrm{I}_{5} & 4.65\end{array}$

Within the limit of the experiments the concentration of acid has no influence on the reduction, and the production of cysteine was also about 98 per cent in these cases.

From the results of the experiments (a) and (b), we see that I.OI $g$. of cystine gives rise to about I.o g. of cysteine by reduction at room temperature.

\section{THE IODINE-METHOD FOR CYSTINE}

For the determination the following solutions are required :-

(1). About 5 per cent potassium iodide aqueous solution.

(2). Exactly 4 per cent hydrochloric acid.

(3). Exactly 2 per cent hydrochloric acid.

(4). $\mathrm{M} / 300 \mathrm{KIO}_{3}$, which is prepared by dissolving $2.14 \mathrm{~g}$. of pure $\mathrm{KIO}_{3}$ in 3 liters of exactly 2 per cent hydrochloric acid. This solution should be standardized for cystine very carefully.

Standardizing of the iodate solution:-Dissolve r.or $\mathrm{g}$. of cystine in 50 c.c. of about 5 per cent hydrochloric acid, add a few decigrams of zinc dust, leave it for 30 minutes at room temperature (about $20^{\circ} \mathrm{C}$ ), shaking from time to time. Filter, wash and make it up to $100 \mathrm{ccc}$. with water. Take I c.c. of the freshly prepared filtrate immediately in a small dry Erlenmeyer flask or in a large test tube, mix with ig c c. of exactly 2 per cent hydrochloric acid, $5 \mathrm{cc}$. of 5 per cent potassium iodide and 5 c.c. of exactly 4 per cent hydrochloric acid, and then titrate with the iodate solution until a yellow color is produced. Insert a thermometer immediately in the mixed liquid to know the temperature at which the titration has been finished. The volume (c.c.) of the iodate solution required corresponds to $0.0101 \mathrm{~g}$. of cystine.

As the volume somewhat varies with the temperature of the experiment, it is convenient, to place I c.c. of the filtrate in each of several 
flasks or test tubes, and to repeat the same experiment several times at different temperatures, and to get a table or a curve showing the relation between the temperature and the required volume of the iodate sulution.

The curve obtained was as follows:

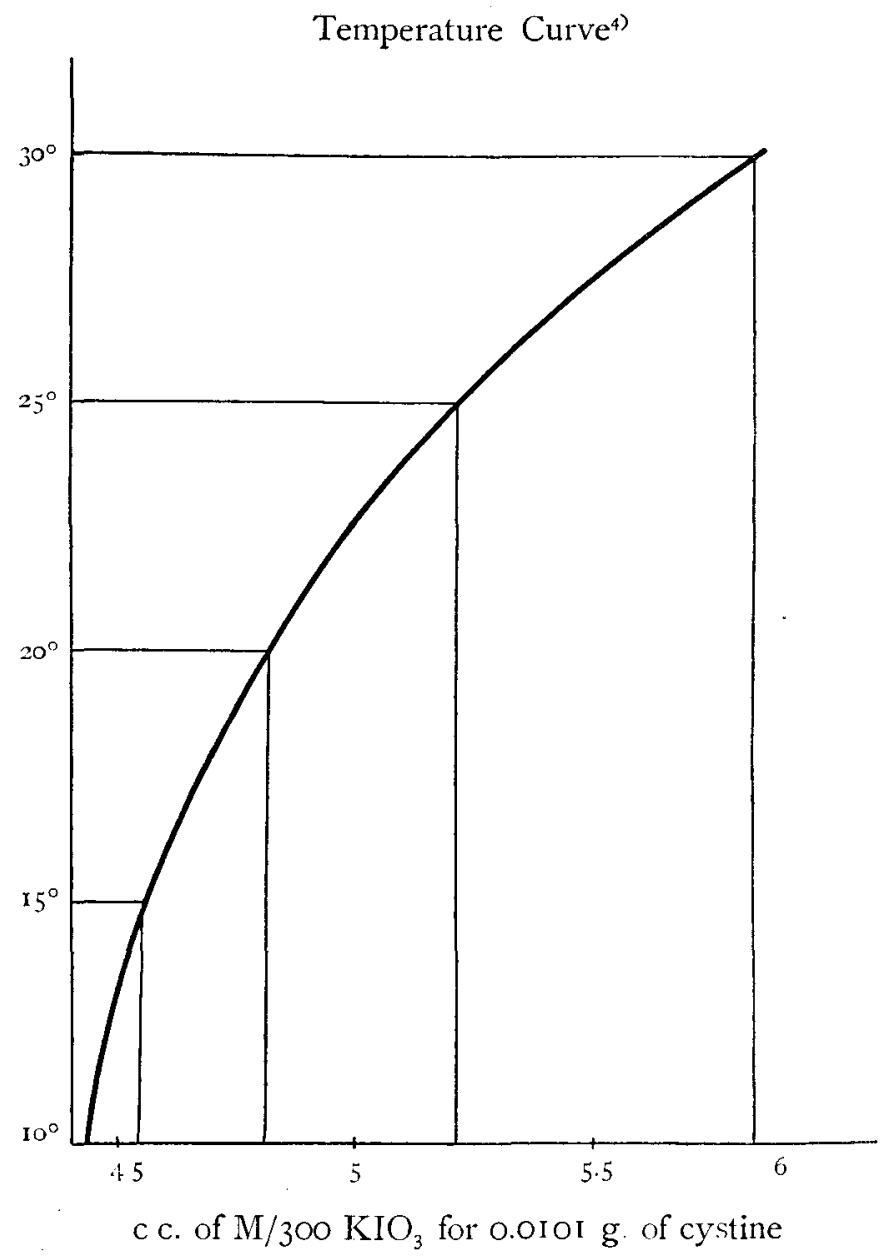

In this temperature curve, the temperature in which the titration was finished was taken as the ordinate, and c.c. of the iodate solution corresponding to the cystine solution as the abscissa. The cystine solution

4) This temperature curve for o.orc $\mathrm{g}$. of cystine is equal to that for o.or $\mathrm{g}$. of cysteine. 
contained $0.010 \mathrm{I} \mathrm{g}$. of cystine, $20 \mathrm{cc}$. of 2 per cent hydrochloric acid, 5 c c . of 5 per cent potassium iodide, and 5 c.c. of 4 per cent hydrochloric acid.

Procedure:-Take from I to $10 \mathrm{~g}$. (usually less than $5 \mathrm{~g}$.) of protein, boil it with about three times its weight of concentrated hydrochloric acid (sp. gr. I. I9) under a reverted condenser, at first in a water bath and then on a sand bath for 20 hours. Evaporate the solution under diminished pressure to remove the excess of the hyclrochloric acid if the solition contained more than $6 \mathrm{~g}$. of hydrochloric acid. Add some water, and decolorize it with the best charcoal by heating for 30 minutes, and then filter and wash with some boiling water. Cool the filtrate, and add a little zinc dust to it for the reduction of cystine to cysteine, leave it for 30 minutes at room temperature, and then filter, wash and make it up to 100 c.c. Take I c c. of the solution for the determination of the concentration of lyydrochloric acid in it, by means of titration with a standard alkali solution. To the residual solution add a calculated quantity of 20 per cent sodium hydroxide (or if necessary hydrochloric acid), to make it into a solution containing exactly 2 per cent of free hydrochloric acid. After ascertaining by titration once more that the solution contains exactly 2 per cent hydrochloric acid, take a definite volume (20 c.c. or less) of the solution in a small dry Erlenmeyer flask or in a large test tube, and make it up to 20 c.c. with exactly 2 per cent hydrochloric acid. Add 5 c.c. of 5 per cent potassium iodide and 5 c.c. of 4 per cent hydrochloric acid, and then titrate with the standard iodate solution until the faintly yellow color produced remains for one minute. Read the temperature of the liquic, calculate the amount of cystine in the 20 c.c. of the solution, using the curve previously obtained. If the temperature was $17.5^{\circ} \mathrm{C}$ the cystine content in the final 20 c.c. is as follows.

$$
\frac{0.010 \mathrm{I} \times \text { required volume of } \mathrm{KIO}_{3}}{4.65}
$$

Remarks:-(a). For the determination of hydruchloric acid, azolithmine was used as indicator.

(b) In this method the sample for a single determination should contain from 0.005 to $005 \mathrm{~g}$. of cysteine in $20 \mathrm{cc}$. of 2 per cent hydrochloric acid solution.

(c). Especial attention is called to the fact that both standardization of the iodate and the determination of cystine must be made with an equal concentration (e.g. 2 per cent) of hydrochloric acid and with freshly reduced solutions. 
(d). If the original hydrolyzed solution contains some cysteine, the results obtained as above express the sum of cystine and cysteine. All the hydrolysates obtained as described, however, contained no cysteine. For the purpose of testing cysteine in the hydrolyzed solution, add a few $\mathrm{c} c$. of potassium iodide and a drop of the iodate. In presence of cysteine the solution remains colorless, but in its absence it gives a yellow color. This reaction is more sensitive than the well known nitroprusside reaction.

(e). If cysteine is present in the hydrolyzed solution, the separate determination of cystine and cysteine is easily accomplished by the iodine method, titrating a sample-solution before and after the reduction, and calculating from the difference of the two results. In this case, if the titration was made at $17.5^{\circ} \mathrm{C}, 4.65 \mathrm{C} . \mathrm{C}$. of the iodate solution corresponds to o.or $\mathrm{g}$. of cysteine, which will be derived from o.oror $\mathrm{g}$. of cystine by the reduction with zinc and hydrochloric acid at room temperature.

(f). The standard iodate solution keeps at least half a year, if it is preserved in a stoppered brown bottle. A standard other than $\mathrm{M} / 300$ may be used, but of cause it must be standardized for cystine.

(g). It is convenient, for titration to use a burette which gives readings of $1 / 50$ c.c., and also to know the volume of one drop run from the burette.

\section{APPLICATION OF THE METIIOD}

(a). Determination of cysteine in a solution containing amino acids other than cysteine:- $5 \mathrm{~g}$. of hair was completely hydrolyzed as usual, most of the hydrochloric acid in the solution was removed by evaporation in vacuum, and the solution was decolorized, reduced and made up to IoO c.c. The solution contained 2.5 per cent hydrochloric acid but no cysteine. $50 \mathrm{c} \mathrm{c}$. of the solution, therefore, was diluted into 62.5 c.c. with water, to make a solution containing 2 per cent of hydrochloric acid. The acidity was once more ascertained by means of a standard alkali solution, and then $2 \mathrm{c} \mathrm{c}$. of the solution was mixed with i $8 \mathrm{c} \mathrm{c}$. of exactly 2 per cent hydruchloric acid and determined as usual. The content of cystine in the solution was determined to be $\mathbf{1} 2.6$ per cent.

(b). Separate determination of cystine and cysteine :- Ioo c.c. of the sample was prepared, which contained $0.053 \mathrm{~g}$. of cysteine, $0.1 \mathrm{~g}$. of cystine, about $4 \mathrm{~g}$. of hydrolysate of gelatine, a little tyrosine, and $2.27 \mathrm{~g}$. of hydrochloric acid. In this sample cystine and cysteine were determined by the iodine-method. 
Cystine : $-48 \mathrm{c} \mathrm{c}$. of the sample solution was diluted with water into 54.5 c.c. to make it to 2 per cent hydrochloric acid solution, and 20 c.c. of the resulting solution was mixed with 5 c.c. of 5 per cent potassium iodide and 5 c.c. of 4 per cent hydrochloric acid, and then titrated with $M / 300$ $\mathrm{KIO}_{3} .4 .6$ c.c. of the iodate was required at $17.5^{\circ} \mathrm{C}$, or $0.055 \mathrm{~g}$. of cysteine was found in the total sample.

Cystine :-50 c.c. of the original sample was reduced by the addition of zinc dust and then filtered. The filtrate contained exactly 2 per cent of hydrochloric acid. With 10 c.c. of the filtrate, determination was performed as usual, and 7.4 c.c. of $\mathrm{M} / 3 \mathrm{OO} \mathrm{KIO}_{3}$ was required at $17.5^{\circ} \mathrm{C}$. Calculation of the result is as follows :-

$$
\begin{aligned}
& (7.4 \times 0.01 \div 4.65) \times \text { IO }=0.159 \mathrm{~g} . \ldots \text { Sum of cystine and } \\
& \text { cysteine as cysteine. } \\
& (0.159-0.055) \times \text { I.OI }=0.105 \text { g. ..... cystine }
\end{aligned}
$$

Therefore,

$$
\begin{array}{rrrrrrrrr} 
& & & & & & & \text { Applied } & \text { Found } \\
\text { Cysteine } & \ldots & \ldots & \ldots & \ldots & \ldots & 0.053 & 0.055 \\
\text { Cystine } & \ldots & \ldots & \ldots & \ldots & \ldots & 0.100 & 0.105
\end{array}
$$

The slightly higher result might be ascribed to the fact that the gelatine contained a minute trace of cystine.

\section{ACCURACY OF THE METHOD}

(a). The quantity of the standard iodate solution is proportional to the concentration of cystine to a pretty large extent as the following experiments show.

A cystine solution was reduced, filtered and made to a solution of 2 per cent hydrochloric acid A definite portion of the solution was mixed with exactly 2 per cent hydrochloric acid to make up to 20 c.c., and then titrated as usual with following results.

\begin{tabular}{ccc}
$\begin{array}{c}\text { Cystine } \\
\text { applied }\end{array}$ & \multicolumn{2}{c}{$\mathrm{KIO}_{3}$} \\
gequired & c.c. & Theoretical \\
0.07 & 31.5 & 32.1 \\
0.0505 & 23.1 & 23.2 \\
0.0327 & 14.5 & 14.8 \\
0.0101 & 4.65 & $4.65-$ (standard) \\
0.00808 & 3.7 & 3.72 \\
0.00404 & 1.9 & 1.86 \\
0.00202 & 0.98 & 0.93 \\
0.00101 & 0.52 & 0.47
\end{tabular}


(b). A cystine solution of high concentration of amino acids is apt to give a slightly higher result, by reason of the fact that the true acidity of the solution decreases in the presence of much amino acids. But the largest error is less than 3 per cent if a sample solution contains less than Io per cent of amino acids.

For the purpose of showing this fact, $\mathrm{IO} g$. of gelatine and $\mathrm{rog}$. of casein were separately hydrolyzed, and most of the hydrochloric acid was removed by evaporation and then made up to Ioo $\mathrm{cc}$. each containing exactly 2 per cent hydrochloric acid. With these solutions a definite quantity of cysteine freshly produced from cystine was mixed and titrated until the yellow color obtained renaincd only one minute. The results were as follows:

\begin{tabular}{|c|c|c|c|}
\hline \multicolumn{4}{|c|}{ Sample } \\
\hline $\begin{array}{l}\text { Cystine } \\
\text { in } 2 \% \\
\mathrm{HCl}\end{array}$ & $\begin{array}{l}\text { Gelatine } \\
\text { cleavage } \\
\text { products }\end{array}$ & $\begin{array}{l}\text { Casein } \\
\text { cleavage } \\
\text { products }\end{array}$ & $\begin{array}{l}2 \% \\
11 \%\end{array}$ \\
\hline c.c. & c.c. & c.c. & c.c. \\
\hline I & - & - & 19 \\
\hline - & 19 & - & $\mathbf{I}$ \\
\hline I & 19 & - & - \\
\hline- & - & ro & $\mathrm{I}$ \\
\hline & - & 19 & - \\
\hline
\end{tabular}

$\begin{array}{rcc}\text { Required } & \mathrm{KIO}_{3} & \begin{array}{c}\text { Error } \\ \text { in } \% \\ \text { of }\end{array} \\ \text { c.c. } & \text { c.c. } & \begin{array}{c}\text { Theory } \\ \text { number }\end{array} \\ 4.75 & 4.75 & \\ 0.15 & - & \\ 5.00 & 490 & 2.0 \\ 1.30 & - & \\ 6.10 & 6.05 & 0.8\end{array}$

From these results we see that this method gives a slightly higher rcsult in such protcins as contain as small a quantity of cystine as gelatine or casein. But in the case of most of the proteins which contain more than 0.5 per cent of cystine this method gives fairly accurate results.

\section{Part IV}

\section{THE EFFECT OF ACID HYDROLYSIS UPON CISTINE}

As we described in Part III, cystine can be determined in the hydrolyzed solution of proteins by means of the iodine-method. But it seems that the first important question to be solved for the determination of cystine in proteins is whether cystine is decomposed or not during acid hydrolysis.

Regarding this question there are some answers already recordcd. VAx SLIKE. (34) found that when cystine was boiled with 20 per cent hydrochloric acid for 24 hours, only 50 per cent was precipitated by phosphotungstic acid, and he stated that it appears possible that the cystine is partially destroyed during the hydrolysis. Plmmer (28) also found that cystine is decomposed by boilding with concentrated hydrochloric acid for 
5 to 8 hours. From these descriptions we see that cystine is pretty unstable when boiled with mineral acid. If it is true, it is difficult to determine cystine in proteins after acid hydrolysis.

But on the contrary, Gortver and Holm (I3) found that cystine was not readily deaminized. They boiled some amino acids mixture containing cystine with 20 per cent hydrochloric acid for 24 hours, and showed that if all of the ammonia nitrogen was calculated as being derived from the cystine, less than 3 per cent of cystine has been changed Lately IOFFMAN and GoRTNER (14) also determined cystine, after prolonged boiling with hydrochloric acid, by Okups's bromine-method (25), and came to the conclusion that there is no appreciable decomposition of cystinc during ordinary acid hydrolysis of protein, but that the amount of cystine precipitable as phosphotungstate decreases rapidly as a part of the cystine is transformed to its isomer, in which phosphotungstate is readily soluble.

In this present investigation we have confirmed the result obtained by GoRTNer and his co-workers, that there is no appreciable decomposition of cystine during the time of the acid hydrolysis under ordinary pressure. They used the bromine-method for the determination of cystine, but we used not only the bromine-method but also the iodine method together with Folin and Looney's colorimetric method (9).

\section{EXPERIMENTS WITH THE BROMINE-METHOD}

(a). $1.97 \mathrm{~g}$. of pure cystine was boiled with 300 c.c. of 20 per cent hydrochloric acid under a reflex condenser. The hydrolyzed solution gave no sulphate reaction to barium chloride After a definite time of boiling as recorded in the following table a certein portion of the solution was withdrawn and cystine was detemined by the bromine-method (25) and by the total sulphur content by Dexis' method (6), with the following results:

\begin{tabular}{|c|c|c|}
\hline \multirow[b]{2}{*}{ Time of boiling } & \multicolumn{2}{|c|}{ Cystine content in the total sample } \\
\hline & $\begin{array}{l}\text { Found by bromine } \\
\text { method }\end{array}$ & $\begin{array}{l}\text { Calculated from } \\
\text { sulphur content }\end{array}$ \\
\hline o hour & $1.97 \mathrm{~g}$ & $1.96 \mathrm{~g}$ \\
\hline 15 & x.97 & г.96 \\
\hline 20 & J.97 & r.95 \\
\hline 25 & 1.93 & 1.96 \\
\hline 30 & 1.97 & 1.95 \\
\hline
\end{tabular}

(b). The same experiments were repeated with sulphuric acid. $2 \mathrm{~g}$. of cystine was dissolved in 300 c.c. of 25 per cent sulphuric acid and boiled under a reflex condenser. Samples for determination were taken after 
$15,20,25$ and $30^{\circ}$ hours and titrated by the bromine-method. The same results as in the case with hydrochloric acid were obtained, namely there was no appreciable decomposition of cystine by boiling with 25 per cent sulphuric acid.

(c). $1.75 \mathrm{~g}$. of cystine was mixed with $15 \mathrm{~g}$. of gelatine and boiled with $300 \mathrm{cc}$. of 20 per cent hydrochloric acid under a condenser. From time to time Ioc.c. of the solution was taken for the determination of cystine by the bromine-method.

Time
$\begin{gathered}\text { Cystine content found in the } \\ \text { total sample }\end{gathered}$
$\begin{array}{ccc}\text { I hour } & & 1.95 \mathrm{~g} . \\ 20 & & 1.95\end{array}$

Somewhat higher results which obtained in every case should be ascribed to the fact that gelatine contains a little histidine and a minute trace of cystine.

\section{EXPERIMENTS WITH THE IODINE METHOD}

(a) Io g. of human hair was hydrolyzed by boiling with $150 \mathrm{c} \mathrm{c}$. of hydrochloric acid of different concentrations, 20,25 and $3^{8}$ per cent, under a condenser. After a definite time as recorded in the following table ro c.c. of the solution was withdrawn with a dried pipette, and cystine was determined by the iodine-method, and also sometimes by FOLIN and Looney's method.

In every case of withdrawing the hydrolysis-flask was weighed for the purpose of ascertaining if the solution had become concentrate by evaporation.

(1). With $20 \% \mathrm{HCl}$,

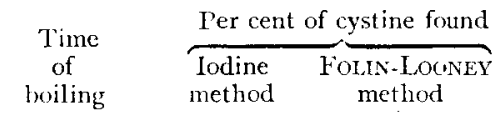

\begin{tabular}{|c|c|c|c|c|}
\hline \multirow[t]{2}{*}{$1-1$} & & I 5 hours & 12.2 & 12.0 \\
\hline & \multirow[b]{4}{*}{ With $25 \% \mathrm{HCl}$} & 20 & I 1.7 & - \\
\hline \multirow[b]{3}{*}{ (2). } & & 25 & 12.2 & - \\
\hline & & 30 & 12.2 & - \\
\hline & & 15 & I 2.2 & 一 \\
\hline \multirow{4}{*}{ (3). } & \multirow[b]{3}{*}{ With $38 \% \mathrm{IICl}$, } & 20 & I 2.4 & - \\
\hline & & 25 & 12.5 & 12,6 \\
\hline & & 5 & I 1.7 & 11.9 \\
\hline & & 8 & II. 7 & - \\
\hline & & so & I 2.2 & - \\
\hline & & 12 & 12.4 & - \\
\hline & & 15 & 12.6 & I 2.8 \\
\hline
\end{tabular}


(b). $10 \mathrm{~g}$. of human hair was hydrolyzed with 3 times its weight of concentrated hydrochloric acid (sp. gr. I.19) for 20 hours. Both the iodine-method and Folin-Looney's method gave exactly the same result, namely I 2.6 per cent of cystine.

From these experimental results we see that there is no appreciable decomposition of cystine during the time, and in the concentration of acid, of ordinary hydrolysis, and both hydrochloric and sulphuric acid gave the same result. Therefore we believe that acid hydrolysis under ordinary pressure is a proper process for the determination of cystine.

We find that for the determination of cystine, it is convenient to use three times its weight of hydrochloric acid and to boil for about 20 hours, although we have always got practically the same result with different concentrations of acid and different intervals of time of boiling.

\section{Part V}

\section{THE CYSTINE CONTENI OF PRO'TEINS}

It is a well known fact that cystine is indispensable for the normal growth of animals. Therefore it is interesting and important to know the quantity of this amino acid in various proteins. But, as far as we know, until recently there was no method by which the cystine content of the protein could be accurately determined.

The cystine content of a number of proteins has been estimated by many authors with VAN SLYKE's method in the phosphotungstic acid precipitate. But VAN SLYKE himself (34) found that cystine is gradually decomposed or altered during the acid hydrolysis, and sometimes only about 50 per cent of the original cystine was precipitated as phosphotungstate. Hofman and Gortner (I4) found that during the hydrolysis cystine is changed into an isomeric form, which phosphotungstate was about four limes as soluble as that of the original cystine. Thus according to the observations of these authors it seems that cystine, after hydrolysis, cannot be accurately determined by means of phosphotungstic acid. Consequently the figures already obtained by VAN SLYKE's method cannot be relied upon as giving the true quantity of cystine in proteins.

Recently FoLIN and LoONey (9) described a culorimetric method for the determination of cystine. Jones, GersdorfF and Moeller (17) approved it as a satisfactory method and applied it for the determination of cystine in a number of proteins. We, however, have failed to confirm the method as satisfactory. 
In the present investigation Folis and LoONEY's method was corrpared with my iodine method described in Part III.

\section{METHODS USED AND CYSTINE _CONTENT}

The cystine determination in various proteins was made according to the colorimetric method of FoLIN and Looner, and also according to the iodine method of the author. Nucleic acid and glucose, which contained no cystine, were also hydrolyzed with strong acid just as in the case of proteins, and treated by both the colorimetric method and the iodinemethod, with the following results as shown in Table $A$.

\section{Table A}

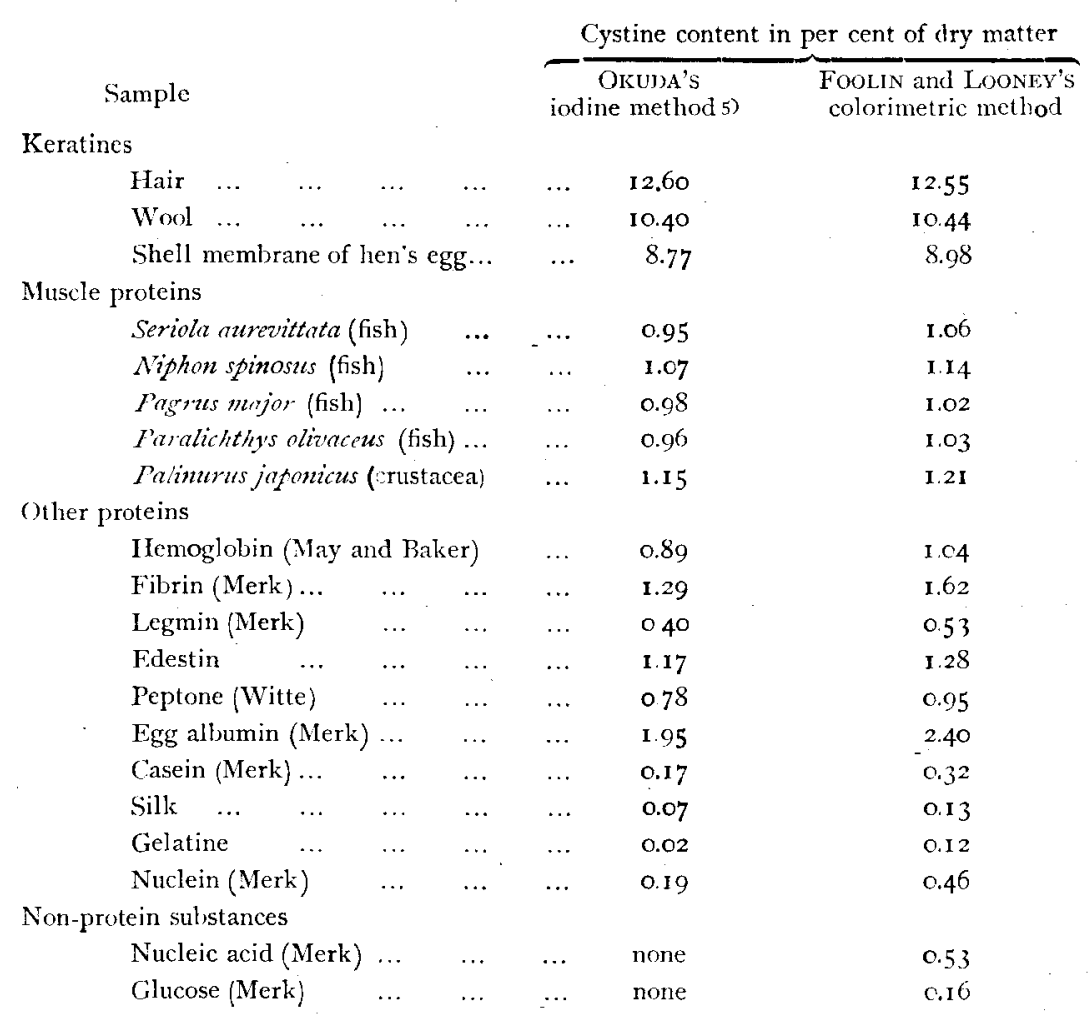

Ogura and Fujikawa (23) lately determined the cystine content of various muscle-proteins of marine animals by means of the iodine method. The results, for the sake of convenience, will be recorded here in 'I'able B.

5) Titrated until the yellow color obtained rcmains only one minute. 


\section{Table B}

\begin{tabular}{|c|c|c|c|c|}
\hline Muscle proteins & & & \multicolumn{2}{|c|}{$\begin{array}{l}\text { Cystine content in per } \\
\text { cent of dry matter }\end{array}$} \\
\hline Scomber juponicus (fish) & $\ldots$ & $\ldots$ & $\ldots$ & 0.82 \\
\hline Spheroides st. $\quad(,)$, & $\ldots$ & $\cdots$ & $\ldots$ & 0.87 \\
\hline Rajasp. $\quad()$, & $\ldots$ & $\ldots$ & $\ldots$ & 0.98 \\
\hline Squarizs jofonicus (" ) $\quad \ldots$ & $\ldots$ & $\ldots$ & $\ldots$ & 0.95 \\
\hline Stichofus joponicus (echinoderma) & $\ldots$ & $\cdots$ & $\cdots$ & 0.75 \\
\hline ISaliotis sp. $\quad$ (mollusca)... & $\ldots$ & $\ldots$ & $\cdots$ & 0.63 \\
\hline Arca influtic & $\ldots$ & $\cdots$ & $\ldots$ & 0.59 \\
\hline Polypues octopotia i & $\ldots$ & $\ldots$ & $\ldots$ & 0.92 \\
\hline Candium muticum ( & $\ldots$ & $\ldots$ & $\ldots$ & $0.7 \mathrm{I}$ \\
\hline Nefiunus peiaricus (crustacca) & $\ldots$ & $\cdots$ & $\cdots$ & 1.12 \\
\hline I'enaeus canaiaculatus (,$)$ & $\ldots$ & $\cdots$ & $\ldots$ & I.19 \\
\hline Chionecetes fhatangium ( & $\ldots$ & $\cdots$ & $\cdots$ & 1.19 \\
\hline
\end{tabular}

\section{DISCUSSION}

In Table $A$ the percentage of cystine in some proteins is given. They were determined by the writer volumetrically as well as colorimetrically in the same proteins. In keratines such as hair and wool, both methods gave equal values, but in the other proteins the values obtained by the colorimetric method were generally higher than those obtained by the iodine-method, espeically was this the case with proteins such as casein, silk and gelatine, being $0.17,0.07$ and 0.02 per cent by the iodine-method and $0.32,0.13$, and 0.12 per cent by the colorimetric method respectively. The cystine content of casein and gelatine, were 0.25 and 0.2 per cent, as determined by FoLIN and Looner themselves (9) and as determined by the same method by Jones, Gersdorff and Mocldik (17), 0.26 and from 0.15 to 0.31 per cent respectively

The question why the colorinctric method gives higher results might be solved by the fact that in the hydrolysates of the proteins there are some substances, others than cystine, which give the same blue color as cystine by the treatment of Forin and Looner. It should be borne in mind, that in the case of keratines which contain much cystine we applied a small quantity of sample for the determination, therefore the influence of the unknown substances upon the colorimetric method was negligrible and it gave quite the same results as the iodine-method, but in the cases of casein, silk and gelatine which contain a little cystine, vice versa.

Since the culorimetric method for cystine is based upon the use of the uric acid reagent of FoLIN and DExIs, it will probably be found that the compounds such as purine bases, which have a similar constitution to uric 
acid and are found in some proteins, give rise to the blue color as cystine does with the reagent. From such a viewpoint I have treated pure guanin sulphate and the hydrolysate of nucleic acid in the same manner as cystine and obtained a blue color as intense as with cystine.

Nucleic acid (Merk) and glucose (Merk) when hydrolysed in the same way as the protein gave 0.53 and 0.16 per cent of cystine respectively by the colorimetric method, while of course none was obtained by the iodinemethod.

From these results we see that FoLIN and LoOLEy's colorimetric method is not satisfactory for the determination of cystine, at least in the proteins which contain either purine or any of the carbohydratc group.

When the proteins tabulated in Table A were completely hydrolyzed as usual, none of the hydrolysates gave cysteine, although its presence in some of the original proteins was ascertained

According to the results of Tables $\mathrm{A}$ and $\mathrm{B}$, it seems that among muscle proteins, those of crustacea contain much more cystine than those of fish and mollusca. This fact seems to have some relation to the blackalteration of the flesh of the crab, which was studied by OKUDA and Mitser (24) several years ago.

\section{Part VI}

ON THE DETLRMINATION OF CYSTINE IN URINE

As far as we know there is no reliable method for the dertcrmination of cysine in urine, although the determination was attempted by many authors such as AbDekillloden (I), Gaskell (I I) Udranszky and BaUMTAx (33) etc.

For this purpose, Loonex (18) lately described a colorimetric method which is an application of FoLin and Loover's method (9) for the determination of cystine. But according to our investigation, which will be described later in detail, Looney's method seems to be unsatisfactory.

The present paper describes a new method for the determination of cystine in urine. It is a modification of the iodine method described in Part III, and depends on the fact that cystine when reduced with nascent hydrogen reacts to iodine quantitatively.

It is true that thiocyanide when reduced also reacts to iodine, but this substance is present in urine usually only in a minute trace and is easily removed by means of charcoal as described below in the case of "Gcneral method." But in abnormal urine containing much thiocyanide, it should be removed by the special treatment as described in the "Special method." 


\section{GENERAL METHOI) (MICRO-IODNE-METHOD)}

This method is directly applicable to normal urine, to the urine containing sugar, and to the urine containing a minute trace of thiocyanide. In the urine containing coagulable proteins and hydrogen sulphide, this method is applicable after removing them. The coagulable protein is removed by boiling the specimen with a few drops of acetic acid, and the hydrogen sulphide by aeration after MLLLLER (2I).

Principle of the method:- Since urine generally contains a very small amount of cystine, for the sake of convenience a definite quantity of cystine, say $10 \mathrm{mg}$. per 50 c.c. of urine, is previously added, and after determination by the iodine-method, this quantity is reduced from that of the total cystine obtained.

Solutions required for the method:-

(1). About 5 per cent potassium iodide aqueous solution.

(2). Exactly 4 per cent hydrochloric acid.

(3). Exactly 2 per cent hydrochloric acid.

(4). Exactly 20 per cent of sodium hydroxide.

(5). Cystine solution containing I $\mathrm{mg}$. of cystine in I c c of 2 per cent hydrochloric acid.

(6). $\mathrm{M} / \mathrm{r} 000 \mathrm{KIO}_{3}$, which is prepared by dissolving $\mathrm{O} 2 \mathrm{I} 4 \mathrm{~g}$. of pure $\mathrm{KIO}_{3}$ in I liter of exactly 2 per cent hydrochloric acid.

Standardization:-For standardization of the iodate solution for cystine, dissolve $0.2 \mathrm{~g}$. of pure cystine in 50 c.c. of about 5 per cent hydrochloric acid, add a few decigrams of zinc dust, leave it for 30 minutes at room temperature. Filter, wash and make it up to Ioo c.c. Take I c.c. of the filtrate in a dry bottle or a test tube, mix with I9 c c. of exactly 2 per cent hydrochloric acid, 5 c.c. of 5 per cent putassium iudide and 5 c.c. of exactly 4 per cent hydrochloric acid, and then titrate with the iodate solution until a yellow color is preduced. Insert a thermoneter immediately in the mixed liquid to know the temperature at which the experiment has been finished. The quantity of the iodate solution corresponds to $2 \mathrm{mg}$. of cystine, at that temperature. It is convenient to repeat the same experiments several times in different temperatures, and to get a table and a curve showing the relation between the temperature and the required volume of the iodate solution.

The temperature curve corresponding to the iodate solution which I used was as follows. 


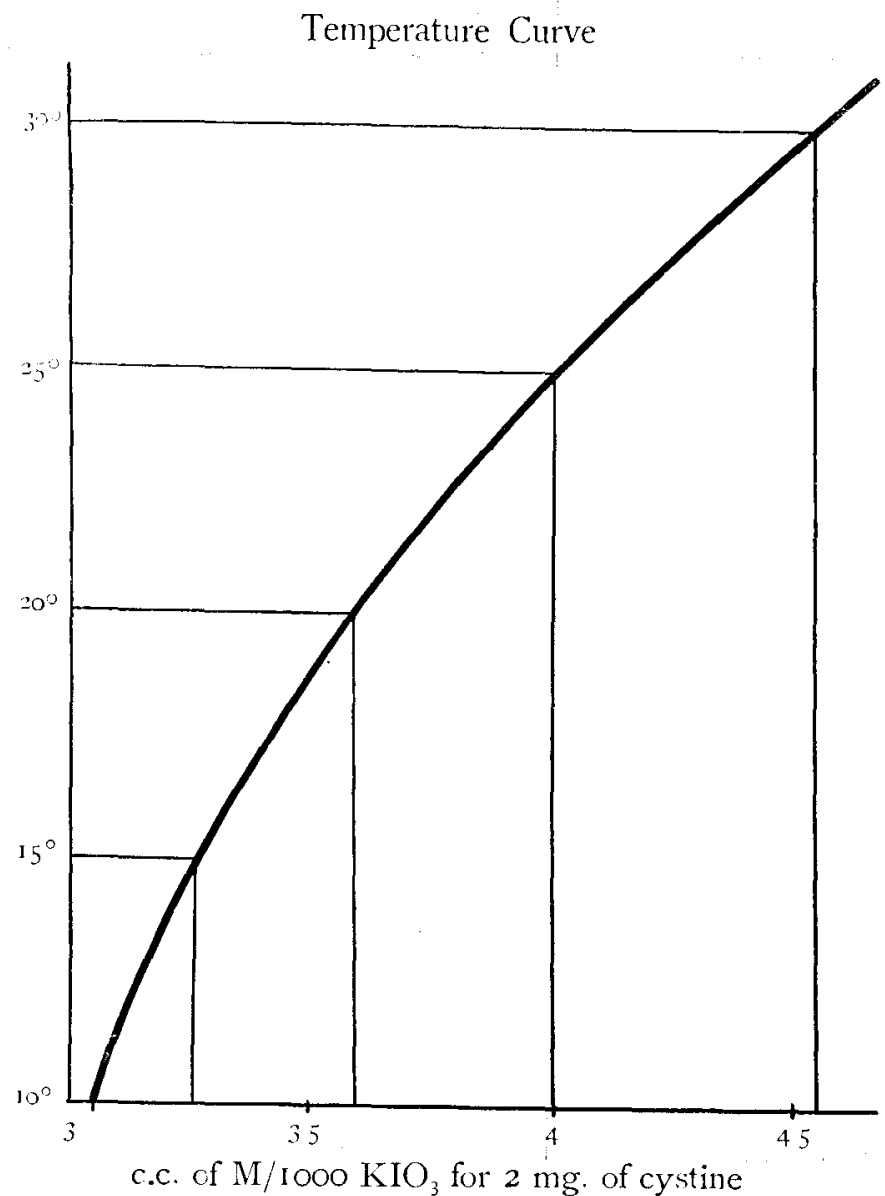

Procclure:-Take 50 c.c. of urine in an Erlenmeyer flask, add io c.c. of the cystine solution, boil for one minute with about $0.5 \mathrm{~g}$. of the best charcoal and then leave it for Io minutes to cool, filter with a small Buchner funnel, wash thrice with $5 \mathrm{cc}$. of water. Add about $0.5 \mathrm{~g}$. of fine zinc dust and $\mathrm{I} 5 \mathrm{c} \mathrm{c}$. of about 20 per cent hydrochloric acid to the filtrate. I cave it for 30 ninutes at room temperature for rẹduction. Filter again with a small Buchner funnel, wash twice with $5 \mathrm{cc}$. of water, and then make the filtrate up to 100 c.c. Take I c c. of the solution for the determination of the concentration of hydrochloric acid in it. To $90 \mathrm{cc}$. of the residual portion of the solution add a calculated quantity of 20 per cent sodium hydroxide to make it into a solution containing exactly 2 per cent of hydrochloric acid. After ascertaining by titration that the solution con- 
tains exactly 2 per cent hydrochloric acid, take 20 c.c. of the solution," mix with 5 c.c. of 5 per cent potassium iodicle and 5 c.c. of 4 per cent hydruchloric acid, and then titrate with the standard iodate solution until the yellow color produced remains for one minute. Read the temperature of the liquid, calculate the amount of cystine in the 20 c.c. of the solution, using the table or the curve previously obtained; for instance, if the temperature was $23^{\circ} \mathrm{C}$, the amount of cystine is $-2 \times$ required c.c. of $\mathrm{KIO}_{3} / 3.8$. From this result get the total amount (mg.) of cystine, and subtract Io mg. from it, then the rest is the qnantity of cystine in $50 \mathrm{ccc}$ of the original urine.

Remarks:- If the original sample contains some cystine, the results obtained as above express the sum of cystine and cysteine as cystine.

The separate determination of cystine and cysteine is easily accomplished, as already described in Part III, titrating the sample solution before and after the reduction.

Perfect decolorization with charcoal is necessary for the ready reduction of the solution with zinc and hydrochloric acid.

The minute trace of thiocyanide in urine is readily removed by adsorption with charcoal, and it does not redissolve by washing. A trace of cystine is also adsorbed by charcoal but it is easily redissolved by washing.

Most of the remarks given in Part III should be observed.

\section{EXPERIMENTS}

(I). In each of three flasks were placed $10 \mathrm{mg}$. of cystine, $0.05 \mathrm{~g}$. of thiocyanide, and 50 c.c. of Solution $A$ which is an artificial mixture of urine constituents. Furthermore some glucose was added in the second flask and protein in the third, and cystine was deteimined, directly in the fist and second flasks, and aftcr removal of coagulable proteins in the third. In every case values closcly approximating the theoretical were obtained.

Composition of the three samples and the analytical results are shown in the following table:-

\begin{tabular}{llllllllccc} 
Composition of samples & \multicolumn{1}{c}{ No. I } & No. . & No. 3 \\
Solution & A & $\ldots$ & $\ldots$ & $\ldots$ & $\ldots$ & c.c. & 50 & 50 & 50 \\
Cystine & $\ldots$ & $\ldots$ & $\ldots$ & $\ldots$ & $\ldots$ & my & 10 & 10 & 10 \\
KCNS & $\ldots$ & $\ldots$ & $\ldots$ & $\ldots$ & $\ldots$ &, & 0.05 & 0.05 & 0.05 \\
Glucose & $\ldots$ & $\ldots$ & $\ldots$ & $\ldots$ & $\ldots$ &, & - & 500 & 500 \\
Gelatine & $\ldots$ & $\ldots$ & $\ldots$ & $\ldots$ & $\ldots$ &, & - & - & 50 \\
Peptone & $\ldots$ & $\ldots$ & $\ldots$ & $\ldots$ & $\ldots$ &, & - & - & 50 \\
Egg albumine & $\ldots$ & $\ldots$ & $\ldots$ & $\ldots$ &, & - & - & 100
\end{tabular}

6) This solution contains about 2 mg. of cystine and is comparalle to the cystinc solution used for standardization of the iodate solution. 
Analytical results

Cystine found $\quad \ldots \quad \ldots \quad \ldots \quad \ldots \quad \ldots \quad$ my

$\begin{array}{llllllll}\mathrm{I} \operatorname{coss} & \ldots & \ldots & \ldots & \ldots & \ldots & \ldots & ,\end{array}$

$\begin{array}{ccc}\text { No. I } & \text { No. 2 } & \text { No. 3 } \\ 9.92 & 9.96 & 9.90 \\ 0.08 & 0.44 & 0.10 \\ 0.8 & \text { C.4 } & \text { 1.0 }\end{array}$

Remark: Solution A is a mixture of $23 \mathrm{~g}$. of urea, $0.5 \mathrm{~g}$ of uric acicl, $0.5 \mathrm{~g}$. of hippuric acid, $0 . \mathrm{I} \mathrm{g}$. of oxalic acid, $0.7 \mathrm{~g}$. of creatinine, $0.4 \mathrm{~g}$. of ammonium chloride, I I $\mathrm{g}$. of sodium chloride, $1.5 \mathrm{~g}$. of acid sodium phosphate, $1.5 \mathrm{~g}$. of sulphuric acid and $0.3 \mathrm{~g}$. of potassium silicate in one liter.

(2). Similar experiments were repeated witl natural unine instead of the artificial mixture. All the samples contained an equal quantity of cystine but consisted of different constituents. The analytical results in all the samples were nearly equal as shown in the following table.

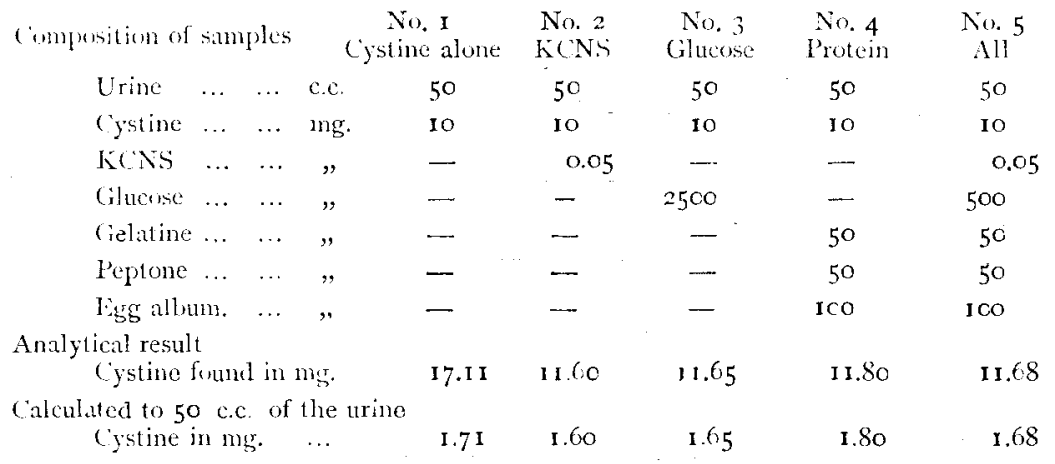

Remark: Cystine was determined, directly in the samples I, 2 and 3 , and after removing the coagulable protein in the samples 4 and 5 .

\section{SPECLAL METHOD}

Most of the normal and abnomal urines contain a minute trace of thiocyanide which is easily removed by means of charcoal during decolorization of the urine; cystine $i_{1}$ such a urine can be determined by the general method as mentioned above.

But in a special case, which is probably very rare and has not been met with yet during the experiments, urine may contain much thiocyanide. In such a case the thiocyanide should be removed by the special treatment. For this purpose modifications ( $A$ and $B$ ) of the general method are described below.

\section{A}

The reduction of thiocyanide with zinc and hydrochloric acid will proceed as follows :

$$
\begin{aligned}
& \mathrm{KSCN}+\mathrm{H}_{2}=\mathrm{H}_{2} \mathrm{~S}+\mathrm{KCN} \\
& \mathrm{KCN}+\mathrm{HCl}+\mathrm{HCN}+\mathrm{KCl}
\end{aligned}
$$


Since the reduction products, , both hydrogen sulphide and hydrocyanic acid react to iodine, they should be removed by means of evaporation in vacuum. The process for determination in this case is as follows.

Take 50 c.c. of uine in a distillating flask, add $10 \mathrm{mg}$. of cystine, some lydrochloric acid and zinc dust, stand for 30 minutes for reduction, and then evaporate into dryness, to remove the reduction products, at a low temperature and under diminished pressure. Dissolve the residue in dilute hydlochloric acid, decolorize with charcoal, reduce again by the addition of little zinc dust, if necessary. Make it up to about 100 c.c. of exactly 2 per cent hydrochloric acid solution, and then detemine cystine as usual by titration with $\mathrm{M} / \mathrm{I} 000 \mathrm{KIO}_{3}$

Fxperiment :- $10 \mathrm{mg}$. of potassium thiocyanide was added to 50 c.c. of normal urine, which contained $1.02 \mathrm{mg}$. of cystine (as determined by the general method), and cystine was determined by the special method A. The result was II.04 $\mathrm{mg}$, namely the cystine content found was $1.04 \mathrm{mg}$.

\section{$\mathrm{B}$}

Thiocyanide is removed as its silver salt as follows:- Take 50 c.c. of urine and IO c.c of cystine solution (which contains $10 \mathrm{mg}$. of cystine and about one per cent sulphuric acid) in a Ioo c.c. volumetric llask. Add silver sulphate (Saturated solution or in powder) until the precipitation of silver thiocyanide ceases. Make up to 100 c.c. with water. Filter through a dry filter paper. Take 80 c.c. of the filtrate, add 10 c.c. of about 20 per cent hydrochloric acid and pulverized barium chloride until the precipitation of barium sulphate ceases. Allow to stand for one hour and then filter again with a dry flter paper. Add a little zinc dust to the filtrate for reduction. Make it into a solution containing exactly 2 per cent hydro chloric acid and determine as usual.

Experiment:- In the experiments we used Solution A instead of natural urine. 50 c.c. of Solution A, $10 \mathrm{mg}$. of cystine, and $5 \mathrm{mg}$. of potassium thiocyanide were placed in each of three volumetric flasks of 100 c.c. capacity Futhermore some glucose was added in the second flask, and both glucose and protein in the third. Cystine was determined by means of the special method $\mathrm{B}$. In the third flask coagulable proteins were previously removed by boiling with acetic acid.

Composition of the samples and results of analysis are as follows :-

$\begin{array}{cccccccccc}\text { Composition of samples } & & & & & \text { No. I } & \text { No. } 2 & \text { No. } 3 \\ \text { Solution } A & \ldots & \ldots & \ldots & \ldots & \text { c.c. } & 50 & 50 & 50 \\ \text { Cystine } & \ldots & \ldots & \ldots & \ldots & \ldots & \text { mg. } & 10 & 10 & 10\end{array}$




\begin{tabular}{|c|c|c|c|c|c|c|c|c|}
\hline $\mathrm{KCNS} \ldots$ & $\cdots$ & $\cdots$ & $\cdots$ & $\cdots$ & $\mathrm{mg}$. & 5 & 5 & 5 \\
\hline Glucose & $\ldots$ & $\cdots$ & $\ldots$ & $\ldots$ & $"$ & - & 500 & 500 \\
\hline Gelatine & $\ldots$ & $\ldots$ & $\ldots$ & $\ldots$ & $"$ & - & - & 50 \\
\hline Peptone & $\ldots$ & $\ldots$ & .. & $\ldots$ & $"$ & 一 & 一 & 50 \\
\hline Egg albumine & $\ldots$ & $\ldots$ & $\ldots$ & $\ldots$ & $"$ & 一 & - & 100 \\
\hline Uric acid & $\ldots$ & $\ldots$ & $\ldots$ & $\ldots$ & , & 25 & 25 & 25 \\
\hline \multicolumn{9}{|l|}{ Analytical results } \\
\hline Cystine found & $\cdots$ & $\ldots$ & $\cdots$ & $\ldots$ & , & 9.6 & 9.6 & 9.5 \\
\hline I oss & $\ldots$ & $\ldots$ & $\ldots$ & & , & 0.4 & 0.4 & 0.5 \\
\hline
\end{tabular}

\section{CISTINE CONTENT OF URINE}

Cystine content of the urine of ten Japanese was determined by means of the micro iodine method (general method) and also by Looner's colorimetric method, with the following results :-

\begin{tabular}{ccc} 
Sample & \multicolumn{2}{c}{ Cystine found in roc c.c. of urine } \\
\cline { 2 - 3 } Looney's method & Iodine method \\
2 & $21.0 \mathrm{mg}$. & $3.8 \mathrm{mg}$. \\
3 & 20.0 & 1.9 \\
4 & 10.5 & 4.7 \\
5 & 15.0 & 6.5 \\
6 & 13.0 & 2.0 \\
7 & 9.0 & 2.0 \\
8 & 16.0 & 2.3 \\
9 & 14.0 & 3.6 \\
10 & 14.0 & 2.3
\end{tabular}

From this result we see that Looner's method gives much higher results than the micro-iodine-method, and that the average cystine content of the urine examined was about $3 \mathrm{mg}$. after the iodine-method.

\section{INFLUENCE OF URINE CONSTITUENTS UPON LOONEY'S METHOD}

Looney's method for the determination of cystine depends on the fact that cystine gives a deep blue color with phosphotungstic acid in presence of sodium sulphite, while uric acid and the other urinary constituents, which reduce phosphotungstic acid, give the same color whether sodium sulphite is present or absent.

But according to our experiments sodium sulphite itself reacts with the uric acid reagent to give a faintly blue color, and some urinary constituents $^{7}$ other than uric acid give a different intensity of color whether in the presence or absence of sodium sulphite. Consequently Looxey's method gives higher results especially in urine poor in uric acid.

7) Solution $\Lambda$ free from uric acid was applied for this experiment. 
To show this fact the following experiments have been performed:-

(I). Io c.c. of distilled water was placed in each of two roo c.c. volumetric flasks, and one of them was treated with sodium carbonate, sodium sulphite (KAHLBALm) and lithium sulphate after Looxkr, and the other was also treated in a similar manner except that no sulphite is added The ratio of the intensity of color in the two flasks was about ten to one

(2). $200 \mathrm{c} \mathrm{c}$ of urine was acidified with IO $\mathrm{C} \mathrm{C}$ of concentrated lydrochloric acid and allowed to stand for a few days Thus most of the uric acid in the urine was precipitated and removed by filtration The filtrate was divided into two equal portions, one of which was mixed with some uric acid And cystine was determined in the two samples by means of Lown's method and by the micro iodine-method The cystine content should be equal in the two samples, but Loover's method gave different results as shown in the table, because the uric acid content is difierent in the two samples

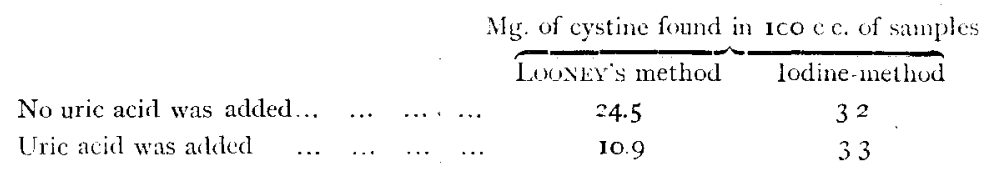

(3). To the urine, which gave $9.7 \mathrm{mg}$. of cystine per Ioo c.c. by Looner's method, some uric acid was added and cystine was determined again by the same method, but the result obtained was only $2.3 \mathrm{mg}$ ler. 100 c.c. This experiment gives the same conclusion as (2).

\section{SUMMARY}

\section{Part I}

1. It was proved that to oxidize one molecule of cysteine to cysteic acid 6 atoms of bromine are required.

2. A method for determining cysteine by titration with a bromate solution in the presence of acid and bromide was proposed.

3. A single determination of cysteine by this bromine method requics only a few minutes. The concentrations of cysteine and acid in samplesolutions have practically no influence upon this method.

\section{Part II}

A method, called the iodine-method, for the determination of cysteine is described. The principle of the method is to titrate cysteine in a hydochloric acid solution, in the presence of iodide, with a standard iodate solution. The procedure of this method is not so simple as that of the 
bromine method, but the method is applicable in the presence of all the cleavage products of proteins. Consequently it is available for the qualitative and quantitative determination of cysteine in amino acids mixture.

\section{Part III}

( I). When treated with nascent hydrogen, cystine and cysteine alone among amino acids react to iodine very actively in acid solution and at room temperature.

(2). A method for the determination of cystine is described. The principle is to titrate cysteine produced by the reduction of cystine, with a standard iodate solution in presence of iodide and acid.

(3). The quantitative method must be made under strictly comparable conditions of the concentrations of acid and of the temperature of the solution etc.

\section{Part IV}

It was verifed that there is no appreciable decomposition of cystine during ordinary acid hydrolysis of proteins, using the bromine-method and iodine method and sometimes FoLIN and I,OONEY's colorimetric method for the determination of cystine.

\section{Part V}

(1). The cystine content in some proteins was determined by Folw and LoONEY's colorimetric method and by OKuDA's iodine method.

(2). The colorimetric method gave too high results. This was ascribed to the fact that there are some substances which are present in the liydrolysate of proteins and give a blue color as cystine does.

(3.). Cysteine was absent in all of the completely hydrolyzed solutions of the proteins examined.

\section{Pa1t VI}

(1). A method for the determination of cystine in urine was described. It is an application of the iodine-method for cystine, and we designated it, for the sake of convenience "micro iodine method" or "general method."

(2). This method, with some modification, may be useful for the determination of cystine in blood and in small quantities of proteins.

(3). Special methods for removing thiocyanide were also described, but they are useful only in very rare cases. 
(4). Looxey's method for the detemination of cystine in urine was studied, but we failed to prove it satisfactory.

In conclusion I wish to cxpress my thanlis to Messis. J. Motomikn and $Y$. Nishijma for their help in analytical work.

From the Biochemical Laboratory, Department of Agriculture, Kyushu Imperial University. July 5, 1925.

\section{REFERENCIS}

(1). Amerhatidin: Z. physiol. Chem. $3^{\circ}, 557$, I903.

(2). Abinkhaldien: Z physisl. Chem. $96,1,1915$.

(3). Arnold : Z. physinl. Chem. 70, 314, I9ro.

(4). Bortssow : Z. physiol. Chem. 19, 5 I 1, 1694.

(5). Danifis and Ricil: J. Binl. Chem. 36, 27, 19I6.

(6). Jowis : J. J3iol. Chem. 8, 40I, I910-II.

(7). Exlinfin: Z. physiol. Chem. 32, 94, rgoo.

(8). Fol.1x: J. Biol, Chem. 8, 9, igro.

(9). Folrn and Loonfy: J. Biol. Chem. 5I, 42I, I 922 .

(io). Frifiminno : Beitr. chem. Physinl. u. Pathol. 3, I, igoz.

(i I). Gaskell: J. Physiol. 36, I43, I907.

(12). Goldmann and Bamann : Z. physiol. Chem. I2, 254, romo

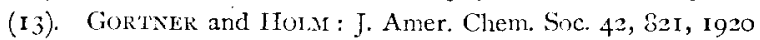

(14). Hoffman and Gortser: J. Amer. Chem. Soc. 44, 341, 1922.

(15). Horkins : Biochem. J. I 5, 286, I921.

(16). Johns and Finks: J. Biol. Chem. 4r, 379, 19zo,-Finks and Jonns: Amer. J. Physiol. 56, 205, 1921,-Johxs and Frnks: Amer. J. Physiol. 56, 208, 1921.-Finks, Jonks and Johns: J. Biol. Chem. 52, 403, 1922 .

(I7). Jonts, GersporfF and Moplikr: J. Binl. Chem. 62, 133, I9z4.

(18). I.OONEY : J. Biol. Chem. 54, I7r, 1922.

(I9). Mörner : Z physiol. Chem. 34, 207, I90I.

(20). Muellate : J. Biol. Chem. 56, 157, 1923.

(2I). Murllar : Cohn, Test and Reagent, 212, I9I6.

(z2). Neuberg and MAYer : Z. physiol. Chem. 44:503, 1905.

(23). Ogura and Fujikawa: J. Agr. Chem. Soc. Japan, 1, 330,1925

(24). Okuda and Matsur : J. Coll. Agr. Imp. Univ. Toliyo, 5, 325, 1916.

(25). OkunA: J. Coll. Agrr. Imp. Univ. Toliyo, 7, 69, Igrg.

(26). Osbonne: Report. Conn. Agr. Exp. Sta. 443, I900.

(27). Osborne and Mendel: J. Binl. Chem. 34, 521, I9I8.

(20). Plimmer : Biochem. J. 7, 31 I, 1913.

(29). Ssadikow and Zelinsky : Biochem. Z. 147, 30, r924.

(3o). Schmid : Proc. Soc. Exp. Biol. and Med. I9, 5o, r9zi.

(31). Scliulz: Z. physiol. Chem. 25, 16, I890.

(32). Suter : Z. physiol. Chem. 20, 564, 1895.

(33). UdoRANSzKy and Baumann : 2. physiol. Chem. 13, 564 , 1869.

(34). Van Slyke : J. Biol. Chem. Io, I5, 191 I.

(35). Winterstein: Z Z physiol. Chem. 34, 153, igor. 